\title{
Chromatographic Applications in Medicine
}

\author{
Özlem Çoşkun ${ }^{1 *}$, Özlem Öztopuz ${ }^{1}$ \\ ${ }^{1}$ Çanakkale Onsekiz Mart University, Faculty of Medicine, Department of Biophysics, Çanakkale, Turkey (ORCID:0000-0002-0741-5001- ORCID: 0000-0002-1373-
} 6311)

(First received 25 April 2019 and in final form 28 October 2019)

(DOI: $10.31590 /$ ejosat.558010)

ATIF/REFERENCE: Çoşkun, Ö. \& Öztopuz, Ö. (2019). Chromatographic Applications in Medicine. European Journal of Science and Technology, (17), 522-529.

$\ddot{O} z$

Kromatografi son yıllarda medikal alanda bir ilacın/metabolitlerinin tanımlanması ve nicelleştirilmesinde tercih edilen analitik yöntemlerden biridir. İlaçları özellikleri ve etkileşimlerine göre ayırmak amacıyla çeşitli kromatografik teknikler geliştirilmiştir. $\mathrm{Bu}$ tekniklerden özellikle yüksek performanslı afinite kromatografisi (HPAC), hücre membran kromatografisi (CMC), karma modlu kromatografi (MMC), yüksek performanslı sıvı kromatografisi (HPLC) klinik öncesi ve klinik çalışmalarda ilaçların biyoanalizi için farmasötik amaçlı kullanılmaktadır. Kromatografinin hızlı ve hassas analitik yöntemler geliştirilmesindeki başarısı, ilaçların AR-GE'deki farmakokinetik özelliklerinin araştırılmasında da üstün özgünlük ve duyarlılık sağlar. Sonuç olarak günümüzde kromotografi tekniği; ilaç-protein etkileşimi, klinik/farmasötik numunelerin incelenmesinde ve kişiye özgü tedavide umut verici bir teknik olarak tercih edilmektedir.

Anahtar sözcükler: Kromatografi, biyofarmasötik, ilaç etkileşimi

\begin{abstract}
Chromatography has been preferred in the medical field as one of the most important analytical methods used for the identification and quantification of a drug and its metabolites in recent years. Various chromatographic techniques have been developed to differentiate drugs according to their characteristics and interaction types. Among these techniques, particularly High Performance Affinity Chromatography (HPAC), Cell Membrane Chromatography (CMC), Mixed Mode Chromatography (MMC), High Performance Liquid Chromatography (HPLC) are used for pharmaceutical purposes for bioanalysis of drugs in preclinical and clinical studies. The success of Chromatography in the development of rapid and precise analytical methods provides superior specificity and sensitivity in the research of pharmacokinetic properties of drugs in R\&D. In personalized medicine, it is important how the dosage and effect of drugs varies from person to person. In recent years, chromotography has been preferred as a promising technique in the analysis of drug-protein binding and in the examination of clinical or pharmaceutical samples.
\end{abstract}

Keywords: Chromatography, biopharmaceutics, drug interaction

\footnotetext{
* Corresponding Author: Çanakkale Onsekiz Mart University, Faculty of Medicine, Department of Biophysics Çanakkale,Turkey. ORCID:00000002-0741-5001, ozlemcd38@ @otmail.com
} 


\section{Introduction}

Chromatographic methods have become widespread practices for clinical analysis both in routine and research laboratories. Clinical analysis refers to testing of biological materials intended to determine the reliability and efficacy, diagnostic, and therapeutic processes. Chromatographic techniques play an irreplaceable role, particularly in drug, toxicology and biomarker analysis (Van den et al., 2012). In these analysis, such biological materials as whole blood, serum, plasma, urine, feces and tissues and macromolecules, such as lipids and proteins are used (Denoroy et al., 2013; Kortz et al., 2011).

Generally, clinical analysis can be categorized as therapeutic drug monitoring, biomarkers' analysis for laboratory-based diagnostic purposes, and clinical toxicology. Therapeutic drug monitoring (TDM) is commonly used to determine the difference between the minimum active concentrations and minimum toxic concentrations of a drug. Biomarkers are biological compounds that can be operationalized as an indicator of normal biological processes, pathogenic processes, and pharmacological responses. They include low molecular weight metabolites, vitamins, hormones, lipids, peptides, and proteins. They are important specifically for early disease diagnosis, assessment of the disease process, monitoring of drug response, and therapeutic intervention. Clinical toxicology analysis focuses on various toxic agents associated with diseases or clinical symptoms after short-term or long-term exposure (Vlčková et al., 2018).

Clinical analysis requires fast, highly efficient and reliable methods. Low efficiency and sensitivity, and nonspecific interactions in the analyzes used in routine clinical applications cause the reliability of these techniques to decrease. As a result, more specific analyzes should be preferred today than traditional methods. Chromatographic techniques have become more popular in both routine and research laboratories in recent years. The purpose of this review is to provide an overview of the state of the existing chromatographic methods used in clinical analysis. This review summarizes the chromatographic trends in clinical analysis, discusses their advantages and disadvantages, and lastly offers a novel perspective to future research. For this purpose, the chromatography techniques described in the review have been preferred because of their excellent properties in terms of sensitivity, selectivity, time and efficiency compared to the routine analysis and other chromatography techniques.

\section{Some Choromatographic Methods In Clinical Analysis}

A variety of chromatographic techniques have been developed to differentiate the properties and interactions of drugs in clinical analysis. In this section, sensitivity, selectivity, analysis time and yield characteristics of chromatographic methods used in clinical analysis are discussed in detail.

\subsection{High Performance Liquid Chromatography (HPLC) Applications}

HPLC-MS has been employed as a selective alternative technique use in clinical laboratories, especially in endocrinology and toxicology, and to overcome problems related to the analysis of TDM, steroid hormones, and vitamins, new-born screening, and immunoassay. HPLC-MS's basic features are selectiveness, precision, efficiency, and analysis time (Kalogria et al., 2013).

HPLC-MS is a reliable and effective quantitative method in drug and biomarker analysis for the purpose of disease diagnosis and assessment. For the development of the method, the employment of a universal LC method is preferred. Reversed-phase mode is the most commonly used for the analysis of a mobile phase consisting of acetonitrile/methanol and formic/acetic acid, drug, and biomarker especially in the C18 column and gradient mode In drug and biomarker analysis, the C18 column and the mobile phase consisting of acetonitrile/methanol and formic/acetic acid in the gradient mode are most commonly used ones (Fig 1) (Yin et al., 2017).
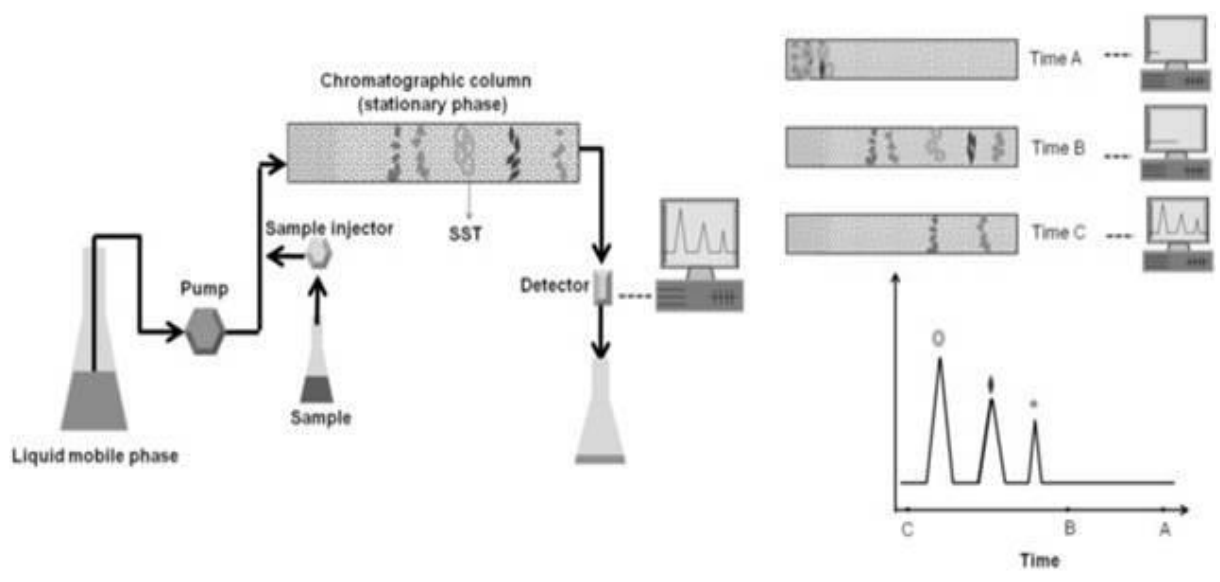

Fig 1. LC-MS's schematized presentation (Yang et al.,2015) 


\subsection{Gas Chromatography (GC) Applications}

Due to its high precision and widespread applicability in the analysis of various physicochemical agents, GC is commonly used as an alternative to GC-MS/MS, HPLC-MS/MS techniques in forensic toxicology, doping analysis, and routine bioanalytical laboratories (Santos and Schug, 2017; Xie and Yuan, 2017). Most of the GC practices use a liquid film coated on a column wall and open tubular capillary columns (Fig 2). GC is also used for metabolomics and lipidomics in targeted analyses of a wide variety of volatile compounds. Such endogenous compounds as fatty acids, steroids, and other hormones, anesthetics, analgesics, antidepressants, antipsychotics and antiepileptics, and such narcotics as cocaine, cannabinoids, amphetamines, $\mathrm{MeOH}$ and breath volatile compounds are the compounds that are typically identified in clinical GC routines. Clinical analysis determines biomarkers of tuberculosis, cancer, neurodegenerative diseases, and diseases associated with metabolic disorders. This analysis is performed in a period of ten minutes (Vlčková et al., 2018)

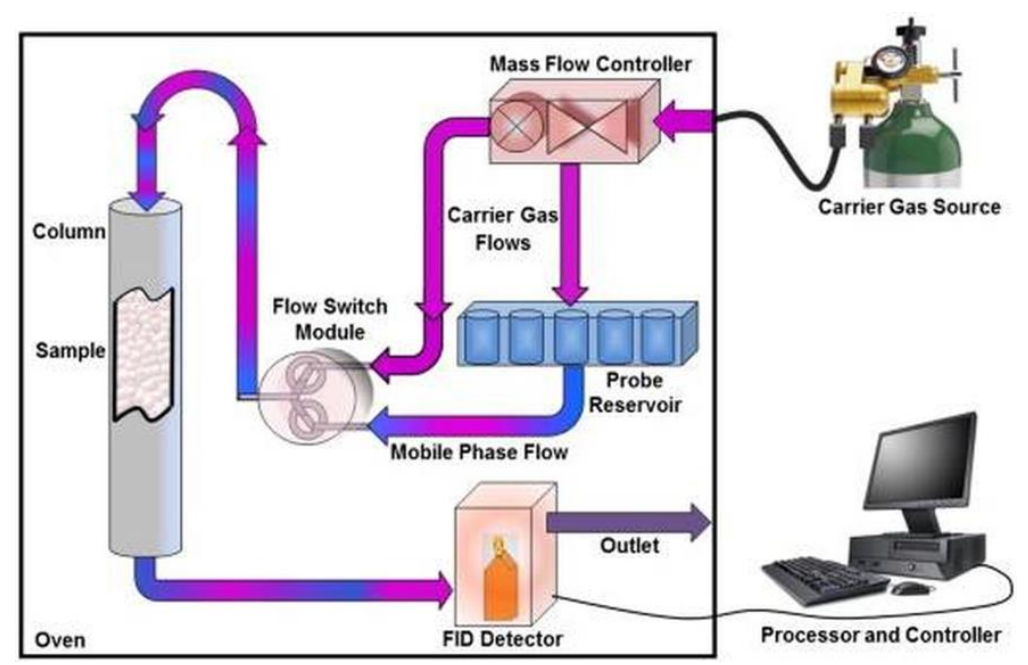

Fig 2. Schematized representation of Gas Chromatography (Mohammadi-Jam and Waters, 2014)

\subsection{Supercritical Fluid Chromatography (SFC) Applications}

Open tubular columns are used in supercritical fluid chromatography as in GC. The advantages of this technique over GC and HPLC are as follows:

(1) Lower viscosity and higher distribution allowing for faster and more efficient separation,

(2) Environment-friendly $\mathrm{CO}_{2}$-based mobile phase mixed with organic solvents,

(3) Broad-spectrum stationary phase.

Thanks to these features, supercritical fluid chromatography allows for a faster analysis with advanced resolution. Moreover, this technique is complementary to GC and HPLC commonly used in clinical analyses. Therefore, SFC has the potential to become a method drawing substantial attention in clinical analyses (Fig 3). Furthermore, it is widely used in drug discovery and development (Tarafder, 2016; Silva and Collins, 2014).

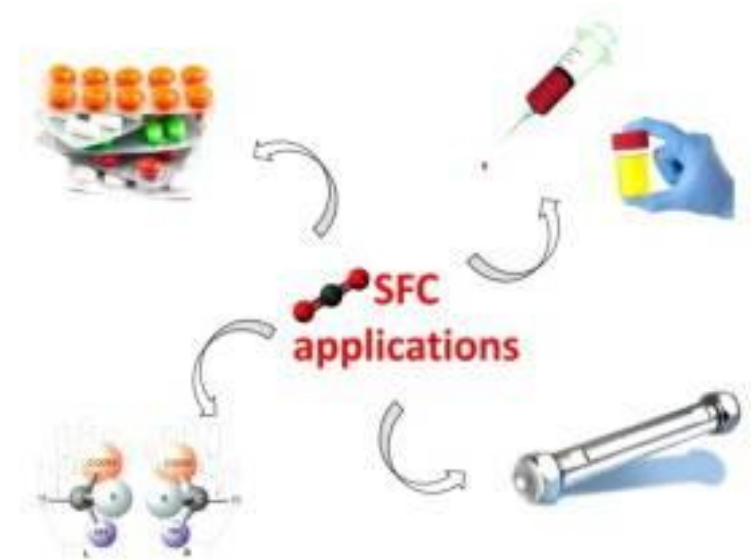

Fig 3. Supercritical chromatography in pharmaceutical analysis (Desfontaine et al., 2015) 
SFC is carried out in clinical analyses to monitor the drugs with serious side effects including citalopram in plasma and ketamine metabolites in urine and antiepileptics and chemotherapeutics (Hegstad, 2017; Fassauer et al., 2017). While lipophilic compounds, carotenoids and fat-soluble vitamins E and D can be generally identified by HPLC in a period of ten minutes, it can be performed by SFC in a few minutes (Fig 4).

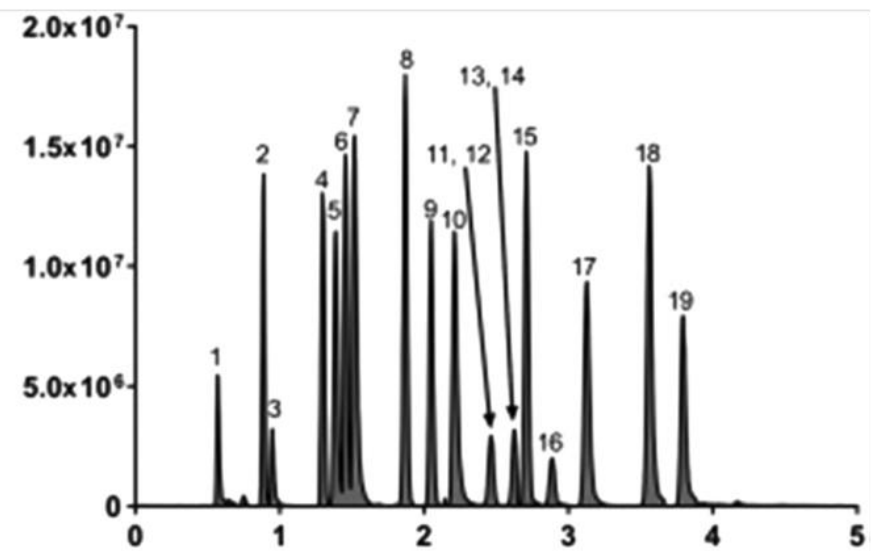

Fig 4. 4-min analysis of 19 endogenous steroids by SFC (Vlčková et al., 2018)

Thanks to the physicochemical characteristic of the mobile phase, SFC is effectively used to screen endogenous hormones, and especially steroid, and to quantify neurotransmitters. The structural separation of similar steroids is presented in Fig 4 . These results can be used for the diagnosis of many diseases (Quanson et al., 2016; Du Toit et al., 2017).

\subsection{High Performance Affinity Chromatography Affinity Chromotography (HPAC)}

Biochemical and chemical agents in the body, antibody's binding with antigen, hormones' interaction with their receptors and drugs' binding with their biological targets or their carrier agents are important in many clinical processes (Hage, 2017). High Performance Affinity Chromatography has become a highly preferred technique to research and characterize interactions between proteins and drugs (Li et al., 2016).

Affinity chromatography is a method relying on specific and reversible absorption of a targeted biomolecule by ligands immobilized on an insoluble support material (matrix) and incorporating binding ends that are complementary to the target molecule (Fig 5). Elusion of the target molecule from the medium can be achieved either by the use of a racing ligand or with a change in the $\mathrm{pH}$, ionic power or polarity of the medium (mobile phase). The mobile phase used during the elusion of a compound from the column should not denature the compound and should not cause any change in its specific activity and function (Ghose and Kumpalume, 2003; Wilchek and Chaiken, 2000; Ostrove, 1990).

Affinity chromatography relies on the reversible interaction between a protein and a specific ligand immobilized in a chromatographic matrix. Affinity chromatography is a type of liquid chromatography that uses a biologically related agent as a stationary phase to purify or analyze specific sample components. High performance affinity chromatography allows for the use of HPLC supports and equipment for an affinity-based separation or analysis (Hage, 2006).

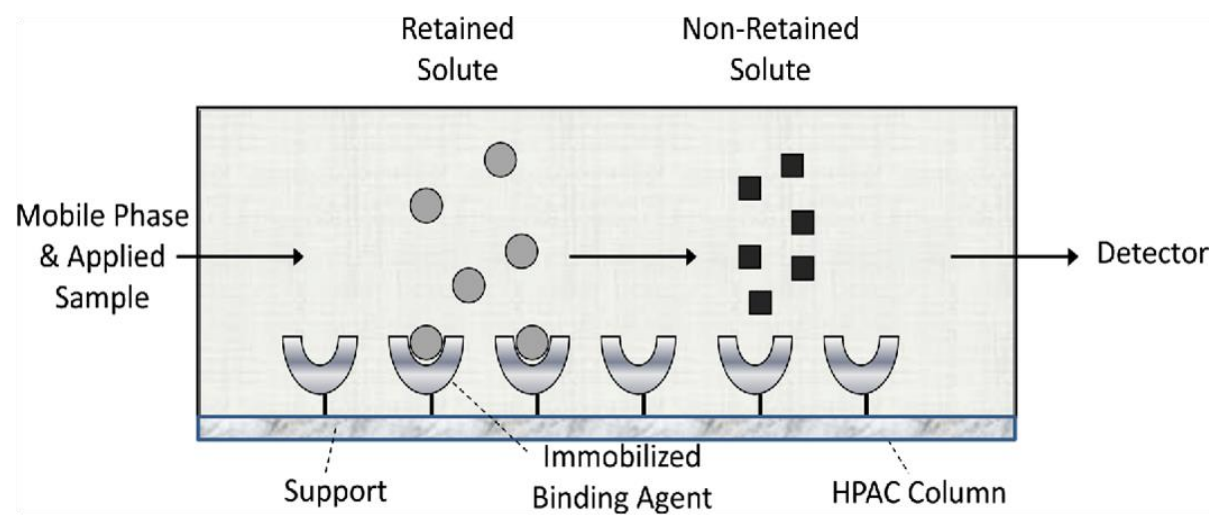

Fig 5. Basic components of High Performance Affinity Chromatography (Hage et al., 2011)

Among the fields of application are high-performance drug screening, studies on modified protein, studies on personalized medicine and drug-drug interaction. HPAC has some characteristics that make it interesting for drug-protein binding studies. For example, This method has a good sensitivity and is relatively high and easy to apply to the routine (Hage et al., 2009). Besides, it can be used together with various types of detectors and it was shown by many studies that it achieves a good correlation with reference 
methods when used to examine the interaction between serum proteins and drugs. Another useful feature of HPAC is its capability to reuse the same protein or binding agent for a multitude of experiments (Hage et al., 2011).

There are various ways a disease can affect the drug-protein interactions in blood. The most important of these ways is the change in the concentration of a protein or a binding agent. For example, the changes in the concentration of other binding agents, e.g. HSA, in blood and in the compounds of these agents, e.g. lipoproteins,. It is known that the level of AGP ( $\alpha 1$-acid glycoprotein) may increase from 2 folds to 5 folds during the acute phase of some diseases (Natarajan et al., 2010; Hochepied et al., 2002).

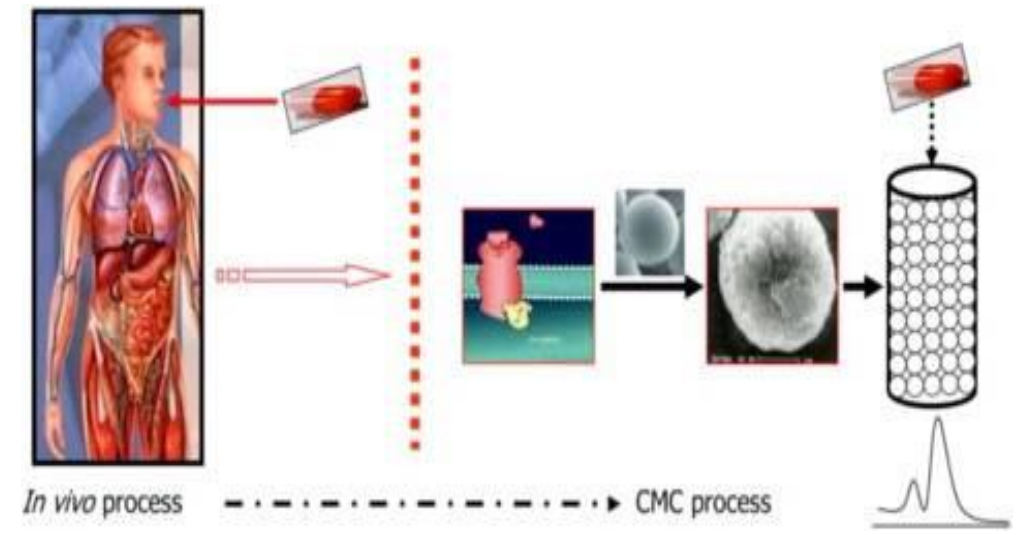

Fig 6. Recent advances in Cell Membrane Chromatography (Hou et al., 2014)

\subsection{Cell Membrane Chromatography (CMC) Applications}

Cell Membrane Chromatography has recently become a practical method to screen active components and to investigate the interaction between drugs and receptors (Fig 6). The interaction between drug and cell membrane receptors is analyzed in vitro. CMC offers several advantages, such as fast and high precision and is suitable for the screening of active components in mixed systems (Hou et al., 2009).

$\mathrm{CMC}$ is a biomimetic affinity chromatography technique using cell membrane receptor as a stationary phase. The stationary phase of cell membrane is developed through the fusion of cell membrane and the adsorption of silicon hydroxyl (Si-OH) groups on the silica gel surface. Silica gel can be used as the ideal carrier of cell membrane (He et al., 2007).

Paraformaldehyde can be cross-linked with the amino group on the surface of protein and its membrane protein facilitates sustaining the spatial configuration. Besides, paraformaldehyde as a protein cross-linking agent may lead to damages to the protein structure and decrease the activity incapable of ensuring the reliability of screening results. Thus, there is need for a novel method to improve cell membrane's ability to attach to the silica gel without damaging the cell membrane (Xiao-Yu et al., 2018).

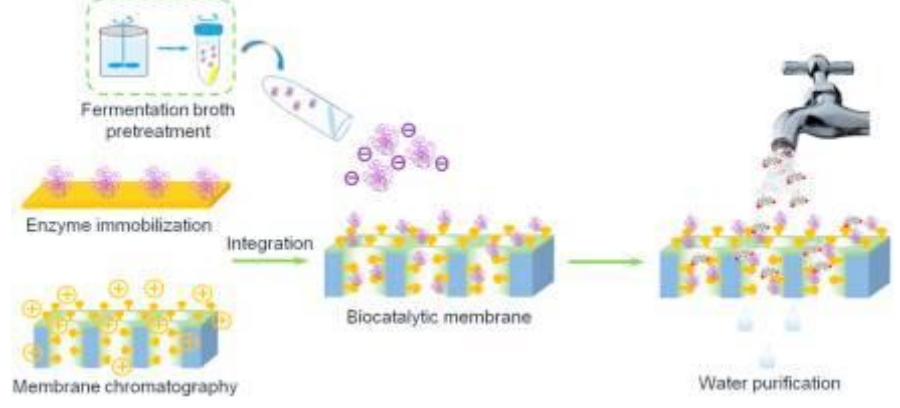

Fig 7. Cell Membrane Chromatography analysis (Fan et al., 2017)

One of CMC's disadvantages is that colons have a short life. The failure of membrane proteins adsorbing on silica gels to maintain their fast movements or activities affects the stability and replicability of the screening results. When using cell membrane columns, receptors on the surface of a cell membrane may gradually lose their original biological activity. Yet a membrane ad sorbed on the surface of a mobile phase can be easily separated when the mobile phase is rinsed. These two reasons cause the column of cell membrane to be short-lived (Fig 7). Generally they fail after a constant use of 48-72 hours. CMC's high-performance drug receptor is promising for interaction characterization. CMC as a drug analysis method with separation and activity screening properties is expected to improve rapidly in terms of integration and automation (Ding et al., 2014).

\subsection{Mixed-mode chromatography (MMC) Applications}

It incorporates superior features for the separation of compounds not binding well nor solving well by typical reversed phase LC methods particularly for polar and charged molecules. Because a single MMC column has multiple-binding feature, it contributes an additional dimension to the separation method with the adjustment of MMC's mobile phase conditions. Additionally, MMC is an 
effective purification method to separate the complex compound matrices or to examine trace amount of analytes precisely (Zhang and Liu, 2016). Mixed-mode columns are advantageous because they have multiple retention processes. The most common of the columns exhibiting both reversed-phase and ion exchange (anionic, cationic or zwitterionic) behavior is the mixed-mode column (Zhang et al., 2010).

MMC allows adjusting the mobile phase/eluant conditions to regulate the interactions of certain analytes. As a new-generation mixed-mode stationary phase, it offers a better separation (Fig 8).

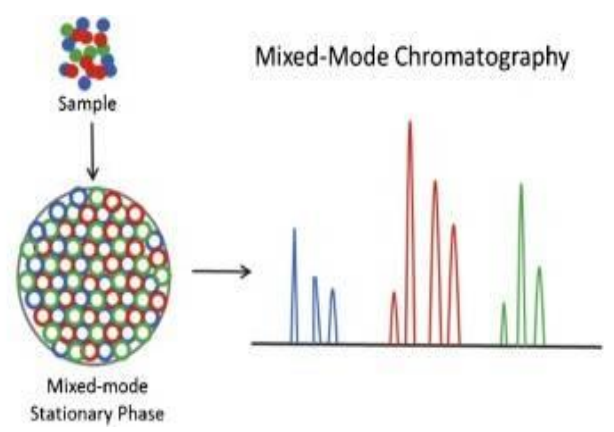

Fig 8. Mixed-mode Chromatography (Zhang and Liu, 2016)

MMC is a chromatographic method incorporating multiple interaction mechanisms of solutes in the stationary phase. MMC is used as a method alternate and complementary to traditional reversed-phase (RP) chromatography, ion exchange (IEX) chromatography, hydrophilic interaction liquid chromatography (HILIC), and normal phase (NP) chromatography (Fig 9). In the past years, MMC has been attracting considerable scholarly attention in both biopharmaceutics and industry (Lämmerhofer et al., 2008). Peptide and protein analysis and purification play a remarkable role in the characterization of buildup of antibodies and heterogeneity (Zhang et al., 2010).

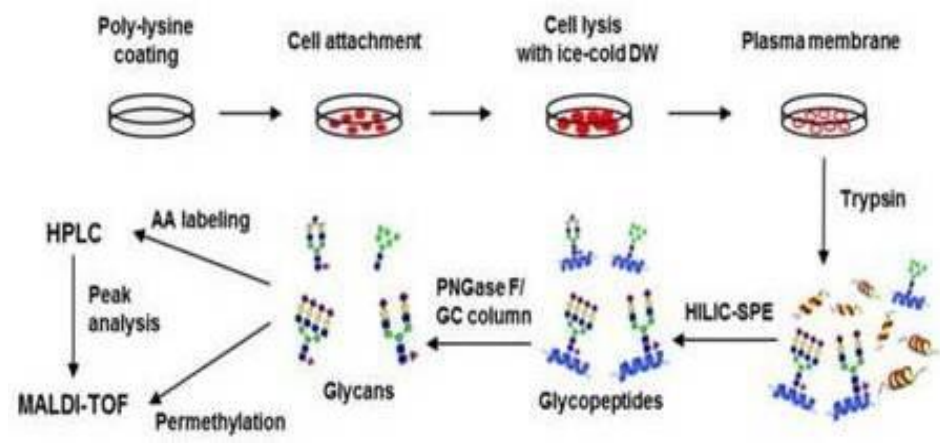

Fig 9. Isolation of plasma membrane protein by MMC method (Mun et al., 2013)

\section{Results and Advices}

This review highlights the significant characteristics of some chromatographic techniques employed in clinical practices in consideration of their precision, selectivity, analysis time, and performance.

Clinical analysis must be offered at a high speed with a high level of efficiency and requires routine application. Spectrophotometric, electrochemical and immunological tests are commonly used in the analysis of various compounds for their high efficiency and universality. In addition, chromatographic techniques also play an indispensable role in the analysis of clinical analysis, particularly in drug screening, toxicology and biomarker analysis. The combination of the novel techniques with the available ones must result in more advanced practices related to affinity chromatography and HPAC in the characterization of biological interactions for the purpose of clinical and pharmaceutical analyses.

There are many advantages that HPAC has contributed to drug-protein interactions and personalized medicine. These advantages include this technique's speed and precision, ability to work with various formats and sensing modes, easiness of automation, and ability to work with a small amount of sample and binding agent. GC is used in more than $30 \%$ of clinical chromatographic practices in toxicology. CMC is a simple, specific and time-saving technique to examine drug-receptor interactions, screening active compounds from complex mixtures, and quality of a product. In recent years, MMC has become more popular in the separation of high-polarity molecules by integrating with conventional reversed-phase and other chromatographic methods.

In conclusion, there is a considerable need in the clinical field for well-devised universal chromatographic methods to simplify the processes and methods to analyze a great many biological compounds. 


\section{References}

Denoroy, L., Zimmer, L., Renaud, B., \& Parrot, S. (2013). Ultra high performance liquid chromatography as a tool for the discovery and the analysis of biomarkers of diseases: a review. Journal of Chromatography B, 927, 37-53.

Desfontaine, V., Guillarme, D., Francotte, E., \& Nováková, L. (2015). Supercritical fluid chromatography in pharmaceutical analysis. Journal of pharmaceutical and biomedical analysis, 113, 56-71.

Ding, X., Chen, X., Cao, Y., Jia, D., Wang, D., Zhu, Z.,\& Chai, Y. (2014). Quality improvements of cell membrane chromatographic column. Journal of Chromatography A, 1359, 330-335.

Du Toit, T., Bloem, L. M., Quanson, J. L., Ehlers, R., Serafin, A. M., \& Swart, A. C. (2017). Profiling adrenal 11ßhydroxyandrostenedione metabolites in prostate cancer cells, tissue and plasma: UPC2-MS/MS quantification of 11 $\beta$ hydroxytestosterone, 11 keto-testosterone and 11 keto-dihydrotestosterone. The Journal of steroid biochemistry and molecular biology, 166, 54-67.

Fan, J., Luo, J., \& Wan, Y. (2017). Aquatic micro-pollutants removal with a biocatalytic membrane prepared by metal chelating affinity membrane chromatography. Chemical Engineering Journal, 327, 1011-1020.

Fassauer, G. M., Hofstetter, R., Hasan, M., Oswald, S., Modeß, C., Siegmund, W., \& Link, A. (2017). Ketamine metabolites with antidepressant effects: fast, economical, and eco-friendly enantioselective separation based on supercritical-fluid chromatography (SFC) and single quadrupole MS detection. Journal of pharmaceutical and biomedical analysis, 146, 410-419.

Felletti, S., Ismail, O. H., De Luca, C., Costa, V., Gasparrini, F., Pasti, L.,\& Catani, M. (2019). Recent achievements and future challenges in supercritical fluid chromatography for the enantioselective separation of chiral pharmaceuticals. Chromatographia, 82(1), 65-75.

Ghose, S., \& Kumpalume, P. (2003). Chromatography: the high-resolution technique for protein separation. In Isolation and Purification of Proteins (pp. 44-69). CRC Press.

Hage, D. S.(2006). Handbook of affinity chromatography. 2nd edition. Volume: 92.

Hage, D. S., Anguizola, J. A., Jackson, A. J., Matsuda, R., Papastavros, E., Pfaunmiller, E.,\& Zheng, X. (2011). Chromatographic analysis of drug interactions in the serum proteome. Analytical Methods, 3(7), 1449-1460.

Hage, D. S., Jackson, A., Sobansky, M. R., Schiel, J. E., Yoo, M. J., \& Joseph, K. S. (2009). Characterization of drug-protein interactions in blood using high-performance affinity chromatography. Journal of separation science, 32(5-6), 835-853.

He, L. C., Wang, S. C., Yang, G. D., Zhang, Y. M., Wang, C. H., Yuan, B. X., \& Hou, X. F. (2007). Progress in cell membrane chromatography. Drug Discov Ther, 1(2), 104-107.

Higgins V, Nieuwesteeg M, Adeli K. (2016). Reference Intervals: Theory and Practice. Clarke W, editor. Contemporary Practice in Clinical Chemistry, 3rd ed: AACC Press, 21-36.

Hochepied, T., Wullaert, A., Berger, F. G., Baumann, H., Brouckaert, P., Steidler, L., \& Libert, C. (2002). Overexpression of $\alpha 1$-acid glycoprotein in transgenic mice leads to sensitisation to acute colitis. Gut, 51(3), 398-404.

Hou, X., Zhou, M., Jiang, Q., Wang, S., \& He, L. (2009). A vascular smooth muscle/cell membrane chromatography-offline-gas chromatography/mass spectrometry method for recognition, separation and identification of active components from traditional Chinese medicines. Journal of Chromatography A, 1216(42), 7081-7087.

Hou, X., Wang, S., Zhang, T., Ma, J., Zhang, J., Zhang, Y., ... \& He, L. (2014). Recent advances in cell membrane chromatography for traditional Chinese medicines analysis. Journal of pharmaceutical and biomedical analysis, 101, 141-150.

Kalogria, E., Pistos, C., \& Panderi, I. (2013). Hydrophilic interaction liquid chromatography/positive ion electrospray ionization mass spectrometry method for the quantification of alprazolam and $\alpha$-hydroxy-alprazolam in human plasma. Journal of Chromatography B, 942, 158-164.

Kortz, L., Helmschrodt, C., \& Ceglarek, U. (2011). Fast liquid chromatography combined with mass spectrometry for the analysis of metabolites and proteins in human body fluids. Analytical and bioanalytical chemistry, 399(8), 2635-2644.

Lämmerhofer, M., Richter, M., Wu, J., Nogueira, R., Bicker, W., \& Lindner, W. (2008). Mixed-mode ion-exchangers and their comparative chromatographic characterization in reversed-phase and hydrophilic interaction chromatography elution modes. Journal of separation science, 31(14), 2572-2588.

Li, Z., Beeram, S. R., Bi, C., Suresh, D., Zheng, X., \& Hage, D. S. (2016). High-performance affinity chromatography: applications in drug-protein binding studies and personalized medicine. In Advances in protein chemistry and structural biology (Vol. 102, pp. 1-39). Academic Press.

Matsuda, R., Anguizola, J., Joseph, K. S., \& Hage, D. S. (2011). High-performance affinity chromatography and the analysis of drug interactions with modified proteins: binding of gliclazide with glycated human serum albumin. Analytical and bioanalytical chemistry, 401(9), 2811.

Mohammadi-Jam, S., \& Waters, K. E. (2014). Inverse gas chromatography applications: A review. Advances in colloid and interface science, 212, 21-44.

Mun, J. Y., Lee, K. J., Seo, H., Sung, M. S., Cho, Y. S., Lee, S. G., ... \& Oh, D. B. (2013). Efficient adhesion-based plasma membrane isolation for cell surface N-glycan analysis. Analytical chemistry, 85(15), 7462-7470.

Natarajan, P., Ray, K. K., \& Cannon, C. P. (2010). High-density lipoprotein and coronary heart disease: current and future therapies. Journal of the American College of Cardiology, 55(13), 1283-1299.

Ostrove, S. (1990). Affinity chromatography: General methods. In Methods in Enzymology (Vol. 182, pp. 357-371). Academic Press. 


\section{European Journal of Science and Technology}

Quanson, J. L., Stander, M. A., Pretorius, E., Jenkinson, C., Taylor, A. E., \& Storbeck, K. H. (2016). High-throughput analysis of 19 endogenous androgenic steroids by ultra-performance convergence chromatography tandem mass spectrometry. Journal of Chromatography B, 1031, 131-138.

Santos, I. C., \& Schug, K. A. (2017). Recent advances and applications of gas chromatography vacuum ultraviolet spectroscopy. Journal of separation science, 40(1), 138-151.

Schiel, J. E., \& Hage, D. S. (2009). Kinetic studies of biological interactions by affinity chromatography. Journal of separation science, 32(10), 1507-1522.

Silva, C. G. A. D.,\& Collins, C. H. (2014). Super/subcritical fluid chromatography with packed columns: state of the art and applications. Química Nova, 37(6), 1047-1057.

Tarafder, A. (2016). Metamorphosis of supercritical fluid chromatography to SFC: an overview. TrAC Trends in Analytical Chemistry, 81, 3-10.

Van den Ouweland, J. M., \& Kema, I. P. (2012). The role of liquid chromatography-tandem mass spectrometry in the clinical laboratory. Journal of chromatography B, 883, 18-32.

Vlčková, H. K., Pilařová, V., Svobodová, P., Plíšek, J., Švec, F., \& Nováková, L. (2018). Current state of bioanalytical chromatography in clinical analysis. Analyst, 143(6), 1305-1325.

Wei, F., Hu, Q., Huang, J., Han, S., \& Wang, S. (2017). Screening active compounds from Corydalis yanhusuo by combining high expression VEGF receptor HEK293 cell membrane chromatography with HPLC-ESI-IT-TOF-MSn method. Journal of pharmaceutical and biomedical analysis, 136, 134-139.

Wilchek, M., \& Chaiken, I. (2000). An overview of affinity chromatography. In Affinity Chromatography (pp. 1-6). Humana Press.

Xiao-Yu, W., Xiao-Fei, C., Yan-Qiu, G., Yan, C., Yong-Fang, Y., Zhan-Ying, H., \& Yi-Feng, C. (2018). Progress of Cell Membrane Chromatography and Its Application in Screening Active Ingredients of Traditional Chinese Medicine. Chinese Journal of Analytical Chemistry, 46(11), 1695-1702.

Xie, S. M., \& Yuan, L. M. (2017). Recent progress of chiral stationary phases for separation of enantiomers in gas chromatography. Journal of separation science, 40(1), 124-137.

Yin, L., Shi, M., Wang, T., Zhang, M., Zhao, X., Zhang, Y., \& Gu, J. (2017). A Parallel-Column LC-MS/MS Method for HighThroughput Analysis of Eight Antiepileptic Drugs in Clinical Therapeutic Drug Monitoring. Chromatographia, 80(1), 137-143.

Zhang, K., \& Liu, X. (2016). Mixed-mode chromatography in pharmaceutical and biopharmaceutical applications. Journal of pharmaceutical and biomedical analysis, 128, 73-88.

Zhang, K., Dai, L., \& Chetwyn, N. P. (2010). Simultaneous determination of positive and negative pharmaceutical counterions using mixed-mode chromatography coupled with charged aerosol detector. Journal of Chromatography A, 1217(37), 5776-5784.

Zhu, M. Z., Wu, W., Jiao, L. L., Yang, P. F., \& Guo, M. Q. (2015). Analysis of flavonoids in lotus (Nelumbo nucifera) leaves and their antioxidant activity using macroporous resin chromatography coupled with LC-MS/MS and antioxidant biochemical assays. Molecules, 20(6), 10553-10565. 